\title{
Potential for Technically Recoverable Unconventional Gas and Oil Resources in the Polish-Ukrainian Foredeep, Poland, 2012
}

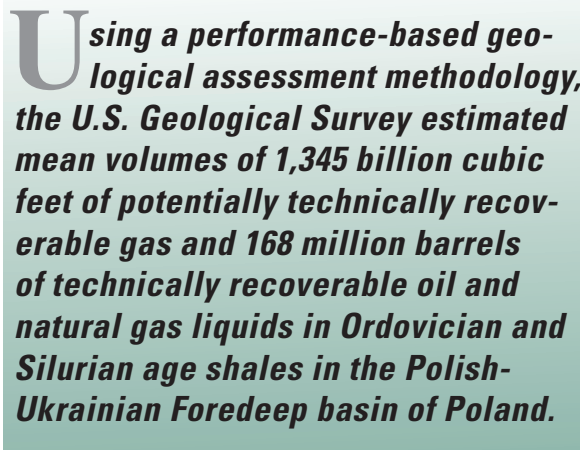

As part of a project to evaluate the potential for unconventional oil and gas resources in priority geological provinces worldwide, the U.S. Geological Survey (USGS) has assessed the potential for shale gas and shale oil resources in the Polish part of the PolishUkrainian Foredeep basin. Resources in the Ukrainian part of the basin are to be considered in a subsequent assessment.

Potentially productive organic-rich shales of Ordovician and Silurian age occur below the surface of the European Plain in a band 20 to $200 \mathrm{~km}$ wide that extends from beneath the Baltic Sea northwest of Gdansk southeastward across Poland in the vicinity of Warsaw and Lublin and into western Ukraine near L'viv and beyond. Geological attributes of the shales are inferred from core and well log data collected in 56 wells drilled before 1990, which have been analyzed and interpreted by scientists of the Polish Geological Institute (PGI). Since 2008, additional wells have been drilled in the area expressly to test shale gas and shale oil potential. However, data and samples from those wells were not made available to the USGS for this assessment.

Potentially productive strata range from tens to hundreds of meters thick, including, in places, almost 100 meters of black marine shales containing more than 2 weight percent total organic carbon (TOC) in type II marine kerogen. TOC concentrations measured in a few core samples are reported to exceed $9 \%$. Thermal maturity of the shales with respect to hydrocarbon generation has been interpreted by PGI scientists (Pawel Poprawa, written commun., 2011) to range from ther-

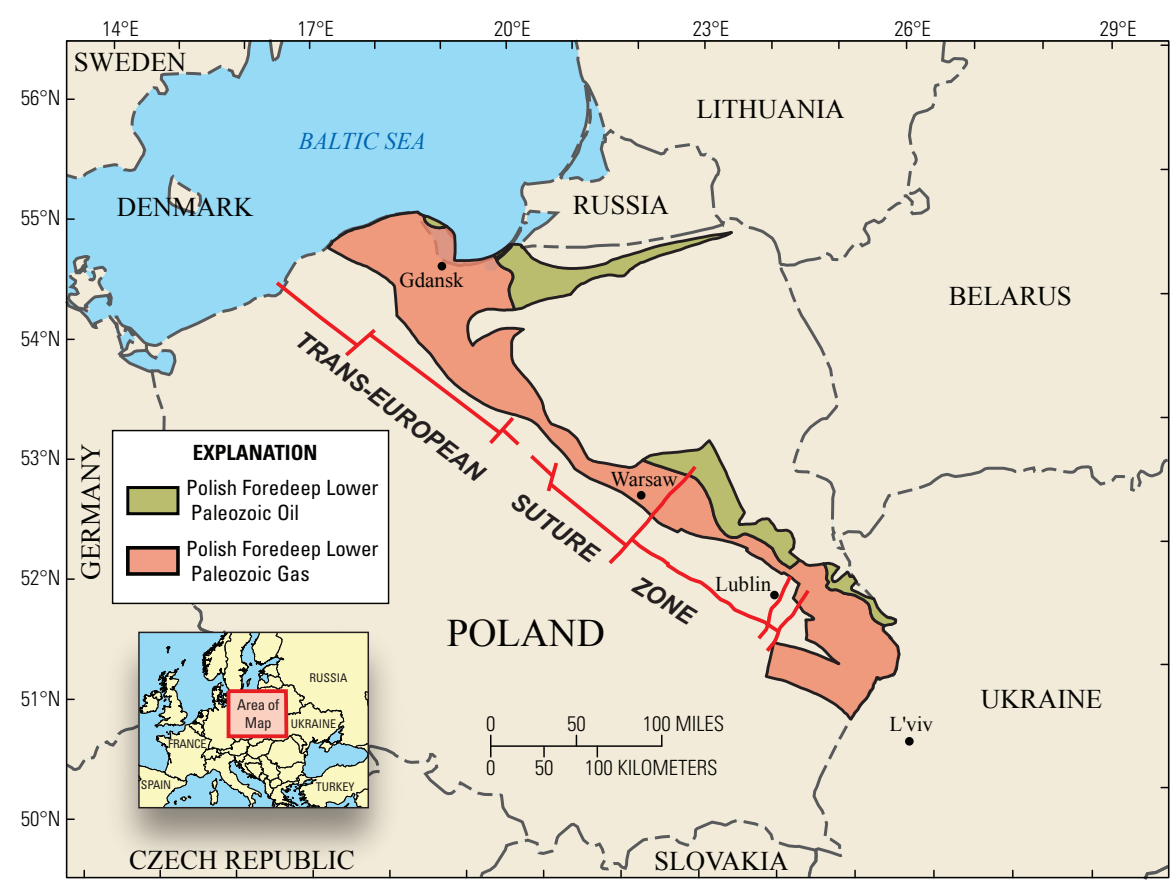

Map showing the assessed areas in the Polish part of the Polish-Ukrainian Foredeep Basin.

The area shown in green represents the Polish Foredeep Lower Paleozoic Oil Assessment Unit. The area shown in red represents the Polish Foredeep Lower Paleozoic Gas Assessment Unit.

mally immature with respect to oil generation $(<0.6 \%$ vitrinite reflectance equivalent) in updip localities along the northeast edge of the basin to supermature $(>3.5 \%$ vitrinite reflectance equivalent) along the southwest edge of the basin near the Trans-European Suture Zone. Thermal maturity information was used to define potentially oil productive and gas productive areas. However, given the uncertainties in data and interpretation, the boundary is highly uncertain. Both Upper Ordovician (Caradoc and Ashgill) and lower Silurian (Llandovery) strata are believed to have resource potential, but the Llandovery shales are considered to be more prospective.

\section{Geological Model for Assessment}

Potentially prospective Ordovician and Silurian shales are parts of a sedimentary succession that accumulated along the southwestern edge of the East European Craton from latest Precambrian (Vendian) to Devonian time. The oldest strata were deposited in a rift-sag basin formed during the earliest stages of continental breakup (Poprawa and others, 1999). Sedimentation continued during Cambrian and Ordovician time within a passive margin setting after continental separation. Tectonic subsidence greatly increased as the continental edge changed from a passive margin to a convergent margin in the Middle to Late Ordovician. High rates of tectonic subsidence coupled with a global sea level rise during the early Silurian permitted sediments rich in organic carbon to accumulate near the continental margin in the newly formed Polish-Ukrainian Foredeep.

Potential shale gas and shale oil reservoirs were rapidly buried beneath a thick accumulation of upper Silurian and Devonian strata that brought the organic-rich shales into temperature conditions suitable for oil generation. In many areas, burial was sufficient to crack the oil to natural gas. Burial history modeling by USGS scientists using data and geological interpretations provided by PGI suggests that oil generation in lower Silurian shales began at depths of about 2,500 meters and that the oil-to-dry-gas 
Table 1. Key assessment input data for shale gas and shale oil assessment units in Poland.

[EUR (estimated ultimate recovery per well), cell size, and success ratios are from U.S. shale gas and shale oil analogs. MMBO, million barrels of oil; BCFG, billion cubic feet of gas; $\mathrm{AU}$, assessment unit; \%, percent. Minimum, median, and maximum values represent the variation about the mean values, and do not reflect the total variation in these parameters. The average EUR imput is the minimum, median, maximum, and calcuated mean.]

\begin{tabular}{|l|r|r|r|r|r|r|r|r|}
\hline \multirow{2}{*}{ Assessment input data } & \multicolumn{3}{|c|}{ Polish Foredeep Lower Paleozoic Gas AU } & \multicolumn{3}{c|}{ Polish Foredeep Lower Paleozoic Oil AU } \\
\cline { 2 - 9 } & Minimum & \multicolumn{1}{|c|}{ Mode } & Maximum & Calculated mean & Minimum & Mode & Maximum & \multicolumn{1}{c|}{ Calculated mean } \\
\hline Potential production area of AU (acres) & 0 & $1,200,000$ & $5,000,000$ & $2,066,667$ & 0 & 760,000 & $1,900,000$ & 886,667 \\
\hline Average drainage area of wells (acres) & 120 & 160 & 200 & 160 & 80 & 160 & 220 & 153 \\
\hline Average EUR (MMB0, oil; BCFG, gas) & 0.1 & 0.2 & 1 & 0.245 & 0.01 & 0.03 & 0.1 & 0.034 \\
\hline Success ratios (\%) & 10 & 50 & 90 & 50 & 10 & 40 & 70 & 40 \\
\hline
\end{tabular}

transition may have begun at depths of about 3,200 m. Oil and gas generated in organicrich lower Silurian (Llandovery) shales and, to a lesser extent, in Upper Ordovician (Caradoc and Ashgill) shales occupy matrix and organic porosity in the same strata. These hydrocarbons, if retained in the shales, may constitute the principal potential unconventional petroleum resource of Poland.

Shale gas and shale oil accumulations in the United States were used as analogs in this assessment. Analog data from U.S. accumulations included mean estimated ultimate recoveries (EUR) from populations of shale gas and shale oil wells, mean drainage areas of directionally drilled wells, and ranges of average well success ratios. Principal input data used in the assessment are listed in table 1.

\section{Assessment Results—-Resource Summary}

The USGS assessed potential technically recoverable shale gas and shale oil resources in the Polish sector of the Polish-Ukrainian Foredeep basin. Results of the assessment are shown in table 2 . The estimated resources, recoverable with existing technology, range from 0 to 4,086 billion cubic feet of gas (BCF), with a mean estimate of 1,345 BCF; from 0 to 172 million barrels of oil (MMBO), with a mean estimate of 62 MMBO; and from 0 to 368 million barrels of natural gas liquids (MMBNGL), with a mean estimate of 106 MMBNGL. The wide range of resource estimates underscores the uncertainty inherent in this assessment.

\section{Further Information}

Supporting geological studies of total petroleum systems and assessment units, and reports on the methodology used in this assessment of the Polish sector of the Polish Ukrainian Foredeep are in progress. Complete assessment results are available at the USGS Energy Web site:

http://energy.usgs.gov.

\section{Acknowledgements}

We thank the scientists of the Polish Geological Institute for sharing their data and for educating us on the petroleum geology of the Polish-Ukrainian Foredeep prior to the assessment. Interpretations and collaborative geological analyses provided by Pawel Poprawa, then of PGI, were particularly helpful.

\section{Selected References}

Kanev S., Margulis, L., Bojesen-Koefoed, J.A., Weil, W.A., Merta, H., and Zdanaviciute, O., 1994, Oils and hydrocarbon source rocks of the Baltic syneclise: Oil and Gas Journal, v. 92, p. 69-73.

Kowalski, A., Wiecław, D., Grotek, I., Kotarba, M.J., and Kosakowsk,i P., 2010, Habitat and hydrocarbon potential of the lower Paleozoic source rocks in the Polish part of the Baltic region: Geological Quarterly, v. 54, no. 2, p. 159-182.

Nehring-Lefeld, M., Modliński, Z., and Swadowska, E., 1997, Thermal evolution of the Ordovician in the western margin of the East-European Platform; CAI and Ro data: Geological Quarterly, v. 41, no. 2, p. 129-138.

Poprawa, P., Šliaupa, S., Stephenson, R.A., and Lazauskienê, J., 1999, Late Vendian-Early Palaeozoic tectonic evolution of the Baltic Basin; regional tectonic implications from subsidence analysis: Tectonophysics, v. 314, p. 219-239.

Polish-Ukrainian Foredeep Assessment Team: Donald L. Gautier, Janet K. Pitman, Ronald R. Charpentier, Troy Cook, Timothy R. Klett, and Christopher J. Schenk.

Edited by Peter H. Stauffer

Graphic design by Judy Weathers

\begin{tabular}{c}
\hline For more information, contact: \\
Donald L. Gautier \\
(gautier@usgs.gov) \\
or \\
Christopher J. Schenk \\
(schenk@usgs.gov) \\
website: http://energy.usgs.gov \\
online at: \\
onto it are available \\
http://pubs.usgs.gov/fs/2012/3102/ \\
\hline
\end{tabular}

Table 2. Assessment results for undiscovered unconventional oil and gas resources of Poland.

[MMBO, million barrels of oil; BCFG, billion cubic feet of gas; MMBNGL, million barrels of natural gas liquids. Results shown are fully risked estimates. For gas accumulations, all liquids are included as NGL (natural gas liquids) category. Undiscovered gas resources are the sum of nonassociated (gas in gas fields) and associated gas (gas in oil fields). F95 represents a 95 percent chance of at least the amount tabulated-other fractiles are defined similarly. Fractiles are additive under the assumption of perfect positive correlation. AU probability is the chance of at least one well within the AU having a production capacity of the minimum estimated ultimate recovery. Gray shading indicates not applicable.]

\begin{tabular}{|c|c|c|c|c|c|c|c|c|c|c|c|c|c|c|}
\hline \multirow{3}{*}{$\begin{array}{l}\text { Provinces, } \\
\text { Total petroleum systems (TPS), } \\
\text { and Assessment Units (AU) }\end{array}$} & \multirow{3}{*}{$\begin{array}{c}\text { AU } \\
\text { prob- } \\
\text { ability }\end{array}$} & \multirow{3}{*}{$\begin{array}{l}\text { Field } \\
\text { type }\end{array}$} & \multicolumn{12}{|c|}{ Total undiscovered resources } \\
\hline & & & \multicolumn{4}{|c|}{ Oil (MMBO) } & \multicolumn{4}{|c|}{ Gas (BCFG) } & \multicolumn{4}{|c|}{ NGL (MMBNGL) } \\
\hline & & & F95 & F50 & F5 & Mean & F95 & F50 & F5 & Mean & F95 & F50 & F5 & Mean \\
\hline \multicolumn{15}{|l|}{ TPS } \\
\hline $\begin{array}{l}\text { Polish Foredeep Lower } \\
\text { Paleozoic Gas AU }\end{array}$ & 0.8 & Gas & & & & & 0 & 908 & 3,794 & 1,246 & 0 & 58 & 347 & 100 \\
\hline $\begin{array}{l}\text { Polish Foredeep Lower } \\
\text { Paleozoic Oil AU }\end{array}$ & 0.8 & Oil & 0 & 52 & 172 & 62 & 0 & 75 & 292 & 99 & 0 & 4 & 21 & 6 \\
\hline $\begin{array}{l}\text { Total unconventional } \\
\text { resources }\end{array}$ & & & 0 & 52 & 172 & 62 & 0 & 983 & 4,086 & 1,345 & 0 & 62 & 368 & 106 \\
\hline
\end{tabular}

